\title{
Politik Kriminal \\ Terhadap White Collar Crime
}

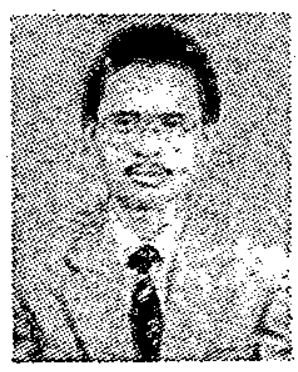

Hanafi

Merebaknya White Collar Crime (WCC), bagaimanapun juga memerlukan sebuah terapi yang antisipatif dengan upaya yang multidimensi.

Berikut ini, Hanafi,secara panjang lebar mengulas tentang politik kriminal terhadap $W C C$.

\section{Pendahuluan}

PEMBERITAAN White Collar Crime (WCC) di media massa yang akhir-akhir ini cenderung meningkat merupakan indikasi bahwa kejahatan tersebut semakin mendapat perhatian masyarakat. Tidak seperti kejahatan konvensional pada umumnya, yang dilakukan oleh orang-orang yang berasal dari kelas sosial ekonomi yang rendah, WCC dilakukan oleh orang yang mempunyai status sosial ekonomi yang tinggi dan mempunyai kedudukan yang terhormat di masyarakat. Pelaku WCC ini meliputi kalangan pengusaba, pejabat dan kalangan profesional. Malpraktek oleh dokter, pengacara atau notaris, korupsi di kalangan pejabat, kolusi penguasa dengan pengusaha, iklan yang menyesatkan, persaingan curang, manipulasi pajak, makanan dan obat-obatan yang membahayakan konsumen, dan pencemaran lingkungan adalah contoh dari WCC.

Kerugian yang ditimbulkan-akibat kejahatan White-collar ini tidak saja kerugian materi tetapi mencakup pula kerugian kesehatan dan keselamatan jiwa yang jauh lebih besar bila dibandingkan dengan kejahatan konvensional. Hal yang lebih ironis lagi terkadang korban tidak menyadari bahwa mereka adalah korban dari kejahatan itu sehingga kejahatan tersebut terus berlangsung dalam waktu yang cukup lama.

Modus operansi kejahatan tersebut dilakukan secara terselubung, terorganisir dan berdasarkan suatu keahlian yang dimiliki oleh seseorang. Oleh karenanya kadang-kadang sulit untuk menentukan siapa yang menjadi korban, siapa yang menjadi pelaku kejahatan, dan bagaimana membuktikan hubungan kausal secara langsung antara perbuatan dengan timbulnya korban. Terlebih lagi sulit untuk menentukan apakah perbuatan tersebut masuk dalam kategori kejahatan. Aparat penegak hukum dengan sarana dan sumber daya yang ada dihadapkan pada tantangan yang cukup besar dalam menanggulangi kejahatan jenis ini.

Menghadapi kenyataan seperti ini, wajar jika kemudian dipertanyakan, sampai sejauh 
mana upaya yang dilakukan dalam rangka menanggulangi WCC. Berbicara mengenai upaya yang dilakukan dalam penanggulangan suatu kejahatan berarti berbicara tentang politik kriminal. Politik kriminal yang menyangkut WCC mempunyai karakteristik khusus. Untuk memahami karakteristik yang bersifat khusus ini perlu dikaji secara mendalam hakekat WCC. Tulisan ini akan mencoba menganalisis karakteristik WCC dan bagaimana politik kriminal sebagai antisipasi yuridis dan non yuridis terhadap penanggulangan kejahatan ini.

\section{Kategori dan Karakteristik WCC}

UNTUK menyamakan persepsi, sebaiknya dipahami terlebih dahulu apa yang dimaksud White Collar Crime. Edwin H. Sutherland ketika menyampaikan pidato bersejarahnya di hadapan American Sosicological Society pada tahun 1930 merumuskan White Collar Crime sebagai kejahatan yang dilakukan oleh orang yang mempunyai status sosial ekonomi yang tinggi dan terhormat dan melakukan kejahatan tersebut dalam kaitan dengan pekerjaannya. (Crime committed by a person of respectability and high socio economic status in the course of his occupation).

Istilah White Collar Crime berkembang dengan konsep dan makna yang bermacammacam. Sebagian ahli menyebut dengan istilah Organizational Crime, Organized Crime, Corporate Crime dan Business Crime. Sebagian lagi memakai istilah Occupational deviance, Corporate and Govemmental deviance, dan Illegal Corporate behaviour. ${ }^{1}$ Perbedan pandangan ini bisa dipahami karena Sutherland sendiri sebagai pencetusnya dalam berbagai uraian memberikan definisi yang mengandung kekacauan. Kadang-kadang ia memfokuskan pada pelaku (offender), terkadang pada pekerjaan (occupational), dan tidak jarang pula ia memfokuskan pada korporasi (corporate). ${ }^{2}$

Sebagai konsekuensi dari pemakaian berbagai istilah dan penekanan fokus perhatian, Joann Miller membagi WCC ke dalam empat kategori:

a. Kejahatan korporasi (Organizational Occupational Crime) b. Kejahatan jabatan (Governmental Occupational Crime)

c. Kejahatan Professional (Professional Occupational Crime)

d. Kejahatan Individual (Individual Occupational Crime) ${ }^{3}$

Kategori pertama, yaitu kejahatan korporasi, dilakukan oleh para eksekutif demi kepentingan dan keuntungan perusahaan yang berakibat kerugian pada masyarakat. Dalam kehidupan sehari-hari sering kita jumpai kejahatan korporasi ini seperti misalnya mencemarkan lingkungan, manipulasi pajak, penipuan iklan, memproduksi barang dan obatobatan yang tidak aman bagi konsumen, mengabaikan kesehatan dan keselamatan kerja, pemalsuan dokumen, dan sebagainya.

Akibat yang ditimbulkan oleh kejahatan korporasi tidak hanya bersifat ekonomi sebagaimana anggapan umum yang berkembang di kalangan masyarakat. Apabila kita kaji lebih dalam, terdapat aspek kekerasan terutama apabila dilihat dari dampaknya terhadap masyarakat. Gangguan kesehatan bahkan kematian adalah salah satu bentuk dampak negatif dari kejahatan ini. Sayang sekali di Indonesia masih sangat terbatas penelitian mengenai masalah ini. Di Amerika Serikat, Reiman dalam buku Steven Box ${ }^{4}$ memperkirakan jumlah orang yang mati akibat resiko ketja adalah. 114.000 per tahun. Dia juga membandingkan dengan orang yang mati akibat pembunuhan, penganiayaan atau keracunan yang hanya mencapai 20.600 orang. Reiman juga menggambarkan bahwa kematian akibat resiko kerja ini mencapai enam kali lebih banyak dari pada pembunuhan.

Di samping menimpa para pekerja, kejahatan korporasi ini juga menimpa para konsumen. Tanpa disadari kejahatan ini dapat menembus ruang dan waktu dalam mencelakakan korbannya. Orang dapat menjadi korban di manapun mereka berada. Mengenai hal ini lebih jauh Frank Parkin menggambarkan:

"Don't feel safe staying at home! This long arm of the corporation's grim reaper is not deterred by such agoraphobic pre- 
cautions. Consumers may be poisoned in their beds by improperly tested medical drugs, they may be killed over their dinner tables by unhy- gienically prepared food, they may be blown up to God knows where by the neighbourhood chemical complex exploding, and they may become fatally diseased in their living rooms by industrial pollution"."

Dilihat dari segi ekonomi akibat yang ditimbulkan oleh kejahatan korporasi ini juga tidak sedikit. Sebuah kasus pelanggaran hukum oleh korporasi bisa mencapai jutaan bahkan milyaran dollar. Joseph F. Sheley membandingkan kerugian yang diderita akibat kejahatan korporasi dengan kejahatan konvensional. Di samping itu dia juga membandingkan hukuman yang diterima oleh pelaku kejahatan korporasi dengan kejahatan konvensional. Dikatakan bahwa:

"The electrical price fixing conspiracy of the 1960, losses amounted so over 2 billion, a sum for greater than the total losses from the 3 million bulglaries in the given year. At the same time, the everage loss from a larceny theft is $\$ 165$ and from bulglart \$422: And the persons who conmit these offences may receive sentences of as much as five to ten years, or even longer. For the crimes committed by the large corporations the sole punishment often consist of wamings, consent orders, or comparatively small fines". ${ }^{6}$

Mencermati uraian Sheley di atas bisa kita bayangkan betapa besar kerugian yang diderita akibat kejahatan korporasi. Dan lebih ironis lagi dikatakan bahwa hukuman yang diterima oleh pelaku kejahatan konvensional jauh lebih berat apabila dibandingkan dengan kejahatan korporasi. Disebutkan bahwa hukuman untuk pelaku kejahatan konvensional mencapai 5-10 tahun penjara, sementara untuk kejahatan korporasi hukuman hanya berkisar pada peringatan, perjanjian atau denda yang jumlahnya relatif kecil.

Kategori kedua adalah kejahatan yang dilakukan oleh pejabat atau birokrat seperti misalnya tindakan sewenang-wenang yang dapat merugikan masyarakat, korupsi, manipulasi, kolusi, dan berbagai jenis kejahatan yang berkaitan dengan kekuasaan dan kewenangan yang dimiliki.

Kejahatan yang dilakukan oleh pejabat atau birokrat juga tidak kalah dampaknya terhadap masyarakat bahkan dapat dikatakan meluas ke segala aspek kehidupan masyarakat. Korupsi adalah salah satu contoh yang sangat menggejala sejak dulu hingga sekarang. Kejahatan bentuk ini menurut anggapan masyarakat merupakan momok yang paling berbahaya dibanding dengan kejahatan bentuk lain. $\mathrm{Di}$ samping itu kejahatan bentuk ini merupakan kejahatan yang paling sukar dideteksi dan oleh karena itu juga paling sulit apabila dibandingkan dengan bentuk WCC yang lain.

Kategori ketiga, pelaku kejahatan mencakup berbagai lapangan kerja seperti dokter, notaris, pengacara, insinyur, psikiater, pialang, dan berbagai jenis profesi lain yang mempunyai kode etik khusus. Kejahatan dalam bentuk ini biasa disebut sebagai malpraktek.

Untuk kejahatan profesi di samping kerugian yang bersifat ekonomi juga menyangkut kesehatan dan keselamatan jiwa seseorang. Lebih jauh lagi akibat dari perbuatan ini dapat merusak mental masyarakat terhadap suatu profesi yang mereka anggap terhormat. Akibatnya, tidak menutup kemungkinan dapat menjadi faktor kriminogen untuk timbulnya kejahatan dalam bentuk lain. Salah satu bentuk kejahatan ini adalah malpraktek di bidang kedokteran seperti praktek aborsi, euthanasia atau tindakan dokter di luar standar profesi. Contoh lain adalah malpraktek yang dilakukan oleh akuntan, notaris, pengacara dañ kejahatan profesi yang dilakukan oleh para profesional lainnya.

Kategori keempat adalah kejahatan yang dilakukan oleh individu untuk mendapatkan keuntungan pribadi. Pekerja yang melakukan perbuatan menyimpang sehingga merugikan perusahaan adalah salah satu bentuk kejahatan kategori ini.

Dari kategori tersebut di atas diketahui bahwa WCC dilakukan tanpa kekerasan, tetapi 
selalu disertai dengan kecurangan, penyesatan, penyembunyian kenyataan, manipulasi, pelanggaran kepercayaan, akal-akalan atau pengelakan terhadap peraturan. Mengingat juga jenis kejahatan White-collar tersebut biasanya dilakukan oleh orang-orang yang cukup pandai (intelectual criminal), maka pengungkapan terhadap kejahatan-kejahatan yang terkait tidak mudah. Apalagi bilamana dikaji karakteristiknya sebagaimana diuraikan berikut ini. ${ }^{7}$

Pertama, kejahatan tersebut sulit dilihat (low visibility), karena biasanya tertutup oleh kegiatan pekerjaan yang normal dan rutin, melibatkan keahlian profesional dan sistem organisasi yang kompleks.

Kedua, kejahatan tersebut sangat kompleks (complexity), karena selalu berkaitan dengan kebohongan, penipuan dan pencurian, serta seringkali berkaitan dengan sesuatu yang ilmiah, teknologis, finansial, legal, terorganisasikan, melibatkan banyak orang serta berjalan bertahun-tahun.

Ketiga, terjadinya penyebaran tanggungjawab (diffusion of responsibility) yang semakin luas akibat kompleksitas organisasi.

Keempat, penyebaran korban yang luas (diffusion of victimization), seperti polusi, penipuan konsumen, dan sebagainya.

Kelima, hambatan dalam pendeteksian dan penuntutan (detection and prosecution) sebagai akibat profesionalisme yang tidak seimbang antara aparat penegak hukum dengan pelaku.

Keenam, peraturan yang tidak jelas (ambiguitas laws), yang sering menimbulkan kerugian dalam penegakan hukum.

Ketujuh, sikap mendua terhadap status pelaku tindak pidana. Dalam tindak pidana ekonomi secara jujur kita harus mengakui bahwa pelaku tindak pidana bukanlah orang yang secara moral salah, tetapi karena melanggar peraturan pemerintah untuk melindungi kepentingan umum.

\section{Politik Kriminal}

USAHA mencegah kejahatan adalah bagian dari politik kriminal. Politik kriminal dapat diberi arti sempit, lebih luas dan paling luas. Dalam ant sempit, politik kriminal digambarkan sebagai keseluruhan asas dan metode yang menjadi dasar dari reaksi terhadap pelanggaran hukum yang berupa pidana. Dalam arti lebih luas, ia merupakan keseluruhan fungsi dari aparatur penegak hukum termasuk di dalamnya cara kerja dari pengadilan. Sedang dalam arti yang paling luas, ia merupakan keseluruhan kebijakan yang dilakukan melahui perundang-undangan dan badan-badan resmi yang bertujuan untuk menegakkan normanorma sentral dalam masyarakat. ${ }^{8}$

Berbicara tentang politik kriminal di Indonesia terhadap penegakan hukum dalam rangka penumpasan atau penegakan White Collar Crime, ditemui gambaran sebagai berikut:

- Disadari bahwa urgensinya semakin besar mengingat potensi destruktif dari WCC yang cenderung semakin besar pula.

- Terdapat concern yang amat besar dari masyarakat terhadap semua jenis kasus WCC.

- Ditemui ketidak-harmonisan interpretasi maupun ketidak-optimalan kerja dalam hal penyidikan maupun penuntutannya.

Kontribusi kelemahan penyidikan maupun faktor-faktor eksternal lainnya terhadap kegagalan penegakan hukum diduga lebih besar ketimbang faktor ada tidak adanya hukum yang mengatur jenis WCC tertentu. Ini berarti, betapapun aturan hukum memadai, sama sekali tidak menjamin semua kasus WCC dapat tuntas di pengadilan.

Melaksanakan politik kriminal berarti mengadakan pemilihan dari sekian banyak alternatif dalam usaha penanggulangan kejahatan. Secara garis besar politik kriminal dapat dilakukan melalui sarana penal dan non-penal. Melalui sarana penal berkaitan dengan kebijakan di bidang hukum. Kebijakan ini dapat berupa kebijakan perumusan undang-undang, kebijakan penegakan hukum dan kebijakan penjatuhan pidana. Jadi ada tiga tahap politik kriminal terhadap suatu kejahatan termasuk WCC. Uraian selanjutnya akan menjelaskan ketiga kebijakan tersebut secara berurutan.

\section{WCC dan Hukum}

APABILA dibuat suatu kategori, apakah WCC mendapat pengaturan dalam hukum 
pidana, paling tidak ada tiga klasifikasi. Pertama, WCC sama sekali belum diatur oleh suatu aturan hukum. Kedua, WCC sudah diatur dalam suatu aturan hukum tetapi belum cukup/ memadai. Ketiga, WCC sudah mendapat pengaturan hukum yang memadai. Sehubungan dengan klasifikasi tersebut, timbul pertanyaan, sejaub mana peraturan perundangan kita mengatur mengenai WCC.

Pengaturan WCC dalam perundangundangan kita sebenarnya tidak hanya terdapat dalam KUHP tetapi juga tersebar di berbagai peraturan di luar KUHP. Walaupun peraturan undang-undang tersebut tidak menyebut secara eksplisit mengenai WCC, akan tetapi dari perumusannya dapat ditarik kesimpulan bahwa berbagai bentuk atau kategori WCC mendapat pengaturan walau belum cukup/memadai. KUHP, misalnya, mengatur berbagai tindak pidana yang dilakukan oleh kalangan pengusaha, penguasa dan kalangan profesional.

Untuk kejahatan di kalangan. pengusaha, baik yang dilakukan secara individual maupun secara kelembagaan/korporasi, nampaknya tidak mendapat porsi yang cukup dalam KUHP. Tindakan pengusaha secara individu seperti suap-menyuap, berkolusi dengan penguasa, manipulasi pajak, persaingan curang, pemalsuan dokumen, dan sebagainya nampaknya tidak ada perbedaan bila tidak pidana tersebut dilakukan oleh yang bukan pengusaha. Sementara itu tindakan pengusaha secara kelembagaan/korporasi juga ditemui masalah apakah korporasi bisa dijadikan sebagai subyek hukum dalam hukum pidana. KUHP yang saat ini sedang berlaku hanya mengakui manusia yang dapat melakukan tindak pidana dan mempunyai kesalahan. Walaupun demikian, ketentuan undang-undang di luar KUHP seperti UU Tindak Pidana Ekonomi, UU Tindak Pidana Korupsi, UU Tindak Pidana Subversi, dan UU Narkotika, mengakui korporasi sebagai subyek hukum dan dapat dipertanggung-jawabkan dalam hukum pidana.

Politik hukum yang memperluas dapat dipidananya selain manusia (dalam hal ini badan hukum) dirasakan sangat mendesak mengingat dampak negatif yang ditimbulkan oleh kemajuan ilmu pengetahuan dan teknologi. Menyadari akan hal ini, pembuat konsep KUHP merumuskan pengakuan terhadap korporasi sebagai subyek hukum. Pemikiran seperti ini dapat dikatakan sebagai langkah maju untuk mengantisipasi tindakan-tindakan ilegal yang dilakukan oleh badan hukum.

Mengenai kejahatan jabatan, baik KUHP maupun undang-undang di luar KUHP memberikan porsi yang cukup besar. Di dalam KUHP, pengaturan mengenai kejahatan jabatan mendapat tempat satu bab tersendiri, yakni Bab XXXVIII pasal 415-436. Sementara itu Undang-undang di luar KUHP seperti Undang-undang Nomor 3 Tahun 1971 khusus mengatur tindak pidana korupsi. Oleh RUU KUHP keberadaan tindak pidana ini tetap dipertahankan bahkan untuk beberapa pasal ancaman pidananya dinaikkan menjadi maksimal seumur hidup atau 20 tahun dan minimal 5 tahun yang sebelumnya di dalam KUHP ancamannya hanya berkisar 3-7 tahun dan tidak ada ancaman pidana minimum.

Pasal-pasal yang memberikan batasan pidana minimal khusus tersebut adalah pasal 415 (penggelapan), pasal 416 (pemalsuan), pasal 417 (menggelapkan/merusak barang bukti), pasal 418 (menerima hadiah/janji yang ada hubungan dengan pekerjaan), pasal 419 (menerima hadiah atau janji agar ia melakukan sesuatu atau tidak melakukan sesuatu), pasal 421 (menyalah-gunakan kekuasaan), pasal $\mathbf{4 2 5}$ (pemerasan), dan pasal 435 (turut campur dalam pemborongan padahal ia bertugas sebagai pengawas).

Ancaman pidana minimal khusus terhadap tindak pidana tersebut merupakan hal baru yang diintrodusir oleh pembuat konsep yang belum kita kenal dalam KUHP lama. Kebijakan seperti ini adalah sangat tepat karena tindak pidana tersebut sangat berbahaya dan menimbulkan dampak yang sangat luas terhadap bangsa dan negara yang pada saat sekarang ini sedang giat membangun menuju masyarakat sejahtera, adil dan makmur.

Untuk kejahatan yang dilakukan oleh kalangan profesional juga mendapat tempat di dalam KUHP di samping ketentuan di luar 
KUHP yang berupa kode etik dari masingmasing profesi. Profesi dokter, pengacara, hakim dan wartawan mendapat tempat walau juga masih belum cukup/memadai. Ancaman pidana bagi.dokter yang melakukan tindak pidana ditambah $1 / 3$ dibanding apabila tindak pidana tersebut dilakukan oleh orang biasa (tidak berprofesi sebagai dokter). Tindak pidana tersebut adalah aborsi, euthanasia, karena kealpaan menyebabkan orang lain mati atau luka berat.

Ancaman pidana terhadap aborsi dan euthanasia berkisar antara 5- 10 tahun, dan 15 tahun apabila tindakan tersebut berakibat meninggal dunia. Ancaman ini tidak mengalami perubahan dalam RUU KUHP. Penulis berpendapat, karena perbuatan tersebut sangat keji dan berdampak luas serta dapat menjadi faktor kriminogen terhadap kejahatan dalam bentuk lain, maka seyogyanya ancaman pidana dinaikkan dan kalau perlu diberi batasan ancaman pidana minimal seoerti pada kejahatan jabatan sebagaimana telah diuraikan di atas.

Kejahatan profesi yang dilakukan oleh pengacara diatur pada pasal 420 KUHP yang rumusannya adalah menerima hadiah atau janji dengan maksud untuk mempengaruhi nasihat tentang perkara yang harus diputus oleh pengadilan, dengan ancaman pidana 9 tahun. Sementara itu dalam konsep RUU ancaman pidananya dinaikkan paling lama 20 tahun dan paling rendak 5 tahun. Penulis berpendapat ancaman ini sesuai dengan rasa keadilan masyarakat. Namun patut disayangkan KUHP maupun RUU tidak mengatur bentuk-bentuk kejahatan lain yang dilakukan oleh pengacara, misalnya menipu, memeras atau menggelapkan uang kliennya. Penulis kira tindak pidana seperti ini patut mendapat pengaturan tersendiri mengingat sering menimpa klien. Sungguh ironis pengacara yang dipercaya oleh klien justru merugikan klien itu sendiri.

Mengenai kejahatan profesi yang dilakukan oleh wartawan, baik KUHP maupun RUU tidak mengatur sedikit pun. Namun apabila kita simak, ada beberapa pasal yang dapat dikenakan terhadap wartawan yang dalam hukum pidana dikenal sebagai delik pers. Pasal-pasal
KUHP yang mengatur mengenai masalah ini adalah:

Pasal 155: Penyiaran pernyataan permusuhan terhadap pemerintah

Pasal 157: Penyiaran pernyataan permusuhan terhadap golongan rakyat

Pasal 161: Penghasutan

Pasal 153: Penyiaran penawaran bantuan untuk melakukan tindak pidana

Pasal 1717: Penyiaran kabar bohong

Pasal 282: Penyiaran yang melanggar kesusilaan

Pasal 137: Penyiaran penghinaan terhadap Presiden dan wakil

Pasal 144: Penyiaran penghinaan terhadap -kepala negara sahabat

Pasal 208: Penyiaran penghinaan terhadap penguasa umum

Pasal 310: Penyiaran penghinaan terhadap seseorang

Subyek dari pasal-pasal tersebut di atas sebenarnya berlaku untuk semua orang. $\mathrm{Na}$ mun apabila dilakukan oleh wartawan melalui media massa, maka perbuatan itu disebut sebagai delik pers. Perlu pemikiran lebih lanjut agar delik pers ini mendapat pengaturan tersendiri dengan ancaman pidana yang lebih berat pula sebagaimana halnya dengan profesi yang lain.

\section{WCC dan Sistem Peradilan Pidana}

PADA uraian di atas sudah digambarkan mengenai pengaturan hukum pidana terhadap White Collar Crime. Dari berbagai pengaturan tersebut sebenarnya cukup memadai walaupun tidak secara eksplisit disebutkan istilah White Collar Crime. Bila diasumsikan bahwa White Collar Crime dan pelakunya perlu dihukum mengingat bahwa itulah satu-satunya cara untuk mengurangi atau mencegah timbulnya kasus-kasus White Collar Crime, ada dua model peradilan pidana yang dikenal dewasa ini. ${ }^{10}$

Model pertama, biasa disebut "model yuridis" mengidealkan cara kerja badan-badan dalam Sistem Peradilan Pidana yang sepenuhnya berorientasi hendak memperjuangkan 
tercapainya keadilan. Undang-undảng dan instansi kehakiman memperoleh peranan fundamental. Segala tindakan peradilan, menurut model ini, harus ditujukan pada upaya-upaya terwujudnya atau ditentukan oleh kata-kata hakim yang bertugas mengucapkan undangundang.

Model kedua, biasa disebut stuurmodel, membebankan pada kegunaan sosial, tertib sosial dan menegakkan hukum sebagai fungsi dan tertib sosial. Model yang dalam kriminologi dikenal dengan "model realitas sosial" ini, dengan demikian jauh lebih dinamis dan terbuka bagi kenyataan-kenyataan faktual. Dalam model ini pula muncul konsep "politik kejahatan" sebagài instrumen penguasa yàng dapat digunakan sewaktu-waktu dengan pertimbangan akan menghasilkan yang terbaik. Sebagai bagiản dari hukum pidana dalam banyak hal bergantung bakal efektif atau tidaknya hukum pidana itu sendiri untuk kasus-kasus yang dihadapi.

Berbeda dengan kejahatan konvensional, proses peradilan pidana khususnya masalah pembuktian terhadap WCC sangat sulit mengingat kejahatan ini sering terselubung dan dilakukan secara cermat. Ákibatnya penuntutan terhadapnya lebih mahal dan menghabiskan banyak waktu, padahal pada saat yang bersamaan biaya sebesar itu diperlukan atau Japat dipakai untuk sejumlah kasus kejahatan konvensional. ${ }^{11}$ Di samping itu, pelaku WCC sering berada dalam posisi yang kuat. Mereka dapat mempengaruhi pemerintah dan anggota legislatif untuk membuat peraturan perundang-undangan yang sesuai dengan kebendak mereka. Bahkan tidak jarang pengadilan pun dapat dipengaruhi oleh mereka sehingga proses pemidanaan terhadap mereka jauh dari yang diharapkan. Mengenai hal ini Joseph F: Sheley mengemukakan:

"Corporations have tremendous power and influence on government; This is not true of ordinary offenders. They exert power through cabinet possisions; through political influence on govermment decisions and trough their ability to block legislation or weaken the ability of govemment regulatory agencies to enforce controle affecting them" ${ }^{\prime 12}$

Yang lebih ironis lagi dalam penegakan hukum terhadap WCC ini adalah, tidak adanya kesadaran dari para pelaku WCC terutama pelaku kejahatan korporasi. Mereka selalu saja berdalih bahwa apa yang mereka kerjakan bukan suatu perbuatan yang illegal dan unethical dan harus dapat dimaklumi sebagaimana digambarkan oleh Sheley:

"There is considerable evidence from opinion surveys that corporate executive believe that unethical and illegal practices are comman. The socio-cultural environment within which many modern American corporations operate actually encourages unethical or criminal behaviour". ${ }^{13}$

Berkaitan dengan hambatan dalam penegakan hukum terhadap WCC ini sudah diduga bila tingkat keberhasilan (sucsess rate) bagi penghukuman kasus-kasus tersebut cukup rendah. Suatu victim survey yang dilakukan di Amerika Serikat juga memperlihatkan bahwa publik menyadari akibat WCC dan menginginkan agar pelakunya dihukum berat, namun ternyata berat hukuman yang dijatuhkan oleh hakim tidak seperti yang diharapkan oleh publik. Dikatakan oleh Miller bahwa "The sanctions actually imposed by sentencing judges do not closely corresponden to the public sentiments about the severity of occupational crime ${ }^{\prime 14}$ Kondisi seperti ini menurut hemat penulis tidak jauh berbeda dengan di Indonesia.

\section{WCC dan Pola Pemidanaan}

PIDANA yang dijatuhkan terhadap pelaku WCC mempunyai tujuan prevensi khusus dan prevensi umum. Prevensi khusus ditujukan agar seseorang yang mempunyai niat jahat supaya menimbang-nimbang resiko pidana yang akan diterimanya. Sedangkan prevensi umum mempunyai tujuan agar orang tidak melanggar aturan hukum. Penjatuhan sanksi terhadap kasus-kasus tertentu membuat orang berpikir 
bahwa sanksi itu dapat juga diberlakukan terhadap mereka apabila mereka melakukan kejahatan serupa. Oleh karena itu prevensi umum ini mengandung pengaruh moral dan pendidikan sosial.

Seandainya hukum pidana digunakan sehingga sanksi pidana diterapkan pada WCC, maka tujuan pemidanaan utama yang harus dipertimbangkan bukannya rehabilitasi dan resosialisasi terpidana, melainkan justru efek moral dan pencegahan dari sanksi pidana. Dalam hal ini pelaku tindak pidana telah mengkhianati kepercayaan masyarakat yang paling besar sehingga pidana harus mencerminkan beratnya kejahatan yang dicela masyarakat. ${ }^{15}$

Masalah lain yang perlu mendapat perhatian adalah mengenai pola pemidanaan yang dijatuhkan terhadap pelaku WCC. Pola pemidanaan hendaknya disesuaikan dengan karakteristik dari WCC tersebut. Menarik apa yang dikemukakan oleh Adrianus Meliala ${ }^{16}$. mengenai model pengbukuman terhadap WCC yang secara relatif membawa "derita" tak kalah berat. Model-model penghukuman tersebut adalah sebagai berikut:

1. Untuk Kejahatan Korporasi:

- hukuman denda

- hukuman Probation (bebas bersyarat, wajib lapor dan kegiatan korporasi diawasi ketat)

2. Untuk Kejahatan Jabatan:

- class justise melalui lembaga PTUN

- sanksi atas dasar PP nomor 30

3. Untuk Kejahatan Profesi:

- sanksi etik oleh asosiasi profesional

- pencabutan kualifikasi jenjang keahlian dalam profesi tertentu oleh pemerintah

4. Untuk Kejahatan Individual:

- tidak ada bentuk hukuman yang khusus

\section{Catatan Penutup}

TERBUKTI bahwa WCC mempunyai karakteristik khusus baik mengenai pelakunya, modus operandinya maupun dampak negatif yang ditimbulkannya apabila dibandingkan dengan kejahatan konvensional. Untuk mengantisipasi hal tersebut, diperlukan upaya-upaya yang khusus pula. Politik kriminal sebagai usaha rasional untuk menanggulangi kejahatan dikaitkan dengan WCC ini paling tidak ada tiga masalah pokok yang perlu mendapat perhatian.

Penama, mengenai ketentuan undangundang yang mengatur WCC. Bagaimanapun ketentuan undang-undang ini mempunyai andil yang cukup besar dalam mengantisipasi WCC. Peraturan perundang-undangan Indonesia dapat dikatakan mengatur cukup lengkap namun masih belum cukup, mengingat kejahatan White-collar ini sangat cepat perkembangannya. Kedua, mengenai Sistem Peradilan Pidana. Sistem Peradilan Pidana yang merupakan-titik sentral dalam upaya menegakkan hukum nampaknya masih ditemui berbagai kendala. Kendala tersebut terutama terletak pada kemampuan aparat penegak hukum yang masih belum memadai dalam menangani WCC. Di samping itu juga sarana dan prasarana yang masih serba kekurangan. Ketiga, mengenai pola pemidanaan. Masalah yang ketiga ini berkaitan dan macam-macam pidana yang harus bervariasi mengingat karakteristik WCC yang mempunyai ciri khusus yang berbeda dengan kejahatan konvensional.

Menghadapi kendala-kendala tersebut di atas diperlukan upaya yang sungguh-sungguh dalam mengatasi berbagai kelemahan dari politik kriminal kita terhadap WCC. Untuk itu penulis merekomendasikan hal-hal berikut:

Pertama, perlu dipikirkan kriminalisasi terhadap perbuatan-perbuatan tertentu yang masih belum mendapat pengaturan dalam perundangan kita. Kedua, perlu dipikirkan peningkatan kualitas aparat penegak hukum yang diimbangi dengan tersedianya sarana dan prasarana yang dibutuhkan. Ketiga, perlu diadakan berbagai alternatif sanksi pidana sehingga pola pemidanaan terhadap WCC sesuai dengan karakteristik yang dimilikinya. Dan terakhir, keempat, yang tidak kalah pentingnya adalah, adanya keinginan politik (political will) dari pemerintah untuk menanggulangi WCC secara tuntas sampai ke akar-akarnya, mengingat kejahatan ini sangat berbahaya bagi kelangsungan hidup dan kesejahteraan masyarakat, bangsa dan negara Indonesia yang kita cintai ini. - 
Hanafi, SH, adalah staf pengajar FH-UII. Alumnus Fakaltas Hukum UII Yogyakarta.

\section{Catatan Kaki:}

1. J.E. Sahetapy, Kejahatan Korporasi, Bandung: PT Eresco, 1994, hal. 11.

2. Mohammad Kemal Dermawan, White Collar Crime; Arti dan Perluasan Konsep: Sebuah Ikhtisar, Artikel Jurnal Ilmu-ilmu Sosial PAUIS-UI, Jakarta: Gramedia, 1994, hal. 14.

3. JoAnn Miller, White Collar Crime, Makalah Seminar White Collar Crime, PAU Bidang Ilmu-ilmu Sosial, Universitas Indonesia, 1991, hal. 1.

4. Frank Parkin, Power, Ciime and Mystification, London and New York: Tavistock Publication. 1983, hal. 26.

5. Ibid.

6. Joseph F. Sheley, Exploring Crime: Reading in Criminology and Criminal Justice, Belmont California: Wodswoth Publishing Company, 1987, hal. 210.

7. Muladi, Kejahatan Orang-orang Terhomat dan Permasalahannya Ditinjau dari Sudut Penegakan Hukum Pidana, Makalah Penataran Nasional Hukum Pidana dan Kriminologi, UNDIP, Semarang, 1993, hal. 5-6.

8. Sudarto, Kapita Selekta Hukum Pidana, Bandung: Alumni, 1981, hal. 113-114.

9. Johannes Sutoyo \& Adrianus Meliala, Politik Kejahatan Terhadap Pelaku White Collar Crime, Jurnal Ilmu-ilmu Sosial, Jakarta: Gramedia, 1994, hal. 12.

10. Lihat Roeslan Saleh, Hukum Pidana sebagai Konfrontasi Manușia Atas Manusia, Jakarta: Ghalia Indonesia, 1983, Lihat juga Johannes Sutoyo \& Adrianus Meliala, Ibid, hal. 11-12.

11. Mohammad Kemal Dermawan, Op. Cit, hal. 20.

12. Josep F. Sheley, Op. Cit, hal. 206.

13. Ibid.

14. JoAnn Miller, Op. Cit, hal. 8.

15. Muladi dan Barda Nawawi Arief, Bunga Rampai Hukum Pidana, Bandung: Alumni, 1992, hal. 5

16. Johannes Sutoyo \& Adrianus Meliala, Op. Cit, hal. 8.

\section{Daftar Pustaka}

Dermawan, Mohammad Kemal, White Collar Crime; Arti dan Perluasan Konsep: Sebuah ikhtisar, Artikel Jurnal Ilmu-ilmu Sosial PAIIS-UI, Jakarta: Gramedia, 1994.
Miller, JoAnn L, "White Collar Crime", Makalah Seminar White Collar Crime, PAU Bidang Ilmu-ilmu Sosial, Universitas Indonesia, 1991.

Muladi, Kejahatan Orang-orang Terhormat dan Permasalahannya Ditinjau dari Hukum Pidana, Makalah Penataran Nasional Hukum Pidana dan Kriminologi, UNDIP, Semarang, 1993.

Muladi dan Barda Nawawi Arief, Bunga Rampai Hukum Pidana, Bandung: Alumni, 1992.

Parkin, Frank, "Power, Crime, and Mystification", London and New York: Tavistock Publication, 1993.

Sahetapy, J.E., "Kejahatan Korporasi", Bandung: PT Eresco, 1994.

Saleh Roeslan, "Hukum Pidana sebagai Konfrontasi Manusia Atas Manusia", Jakarta: Ghalia Indonesia, 1983.

Sheley, Joseph F., "Exploring Crime: Reading in Criminologi and Criminal Justice", Belmont California: Wadswoth Publishing Company, 1987.

Sudarto, Kapita Selekta Hukum Pidana, Bandung: Alumni, 1981.

Sutoyo, Johannes \& Meliala, Adrianus, "Politik Kejahatan Terhadap Pelaku White Collar Crime", dalam "Kejahatan Kerah Putih", Jurnal Ilmu-ilmu Sosial, Jakarta: PT Gramedia, 1994. 